\title{
Technology Acquisition and SMEs Performance, the Role of Innovation, Export and the Perception of Owner-Managers
}

\author{
Edmund Mallinguh ${ }^{1, *(1)}$, Christopher Wasike ${ }^{2} \mathbb{D}$ and Zeman Zoltan ${ }^{3}$ \\ 1 Department of Finance, School of Economics and Regional Science, Szent István University, \\ Páter Károly u. 1, 2100 Gödöllő, Hungary \\ 2 Department of Business Administration, School of Business, University of Nairobi, 30197 Nairobi, Kenya; \\ chris.wasike@gmail.com \\ 3 Finance Management and Control, Institute of Business Sciences and Internal Control, Szent István Egyetem, \\ 2103 Goedoelloe, Hungary; zeman.zoltan@gtk.szie.hu \\ * Correspondence: eddie.mallie@gmail.com
}

Received: 21 September 2020; Accepted: 27 October 2020; Published: 29 October 2020

\begin{abstract}
Sufficient literature supports small and medium 'enterprises' (SMEs) significant role in emerging and mature economies. Still, the same research highlights varying challenges that innovative firms in developing economies face, like access to formal credit and external markets. This study examines the effect of a capital budget's proportion for acquiring new technology and sale performance between 2017-2019 using a sample of 101 Kenyan SMEs. The ordinary least square moderated mediation results indicate that: (1) the proportion of the capital budget allocated for the acquisition of technology positively and significantly influences sales; (2) the index of moderated mediation suggests that the perception of firm owner-managers towards the availability of formal credit moderates the mediated relationship between the capital budget's portion spent on technology and sales as mediated by innovation activities. However, the index is insignificant for the second mediator, export longevity. However, in the final model, both the level of innovation and export longevity positively and substantially affect sales.
\end{abstract}

Keywords: technology acquisition; innovation; export; perception; moderated-mediation

\section{Introduction}

Presently, firms operate in a rapidly changing business environment, and they must evolve too, least they find their processes obsolete and products (or services) less competitive. Customers' demands, preferences, and expectations of products from these firms keep changing too. Business owners and managers must make decisions in an environment of uncertainty while making the most out of limited resources. To remain competitive, firms must secure and maintain technology-businesses need to acquire information on future technology while developing asset maintenance and replacement strategies (Nguyen et al. 2017). Firm maintenance costs increase when technology becomes older due to deterioration. Both new capital and maintenance costs vary over the age of a fixed asset because of technological change. Literature suggests that the optimal asset (technology) lifecycle is always shorter whenever new capital costs decrease faster as the maintenance costs decrease slowly or when both new capital and maintenance costs decrease faster with the same rate (Yatsenko and Hritonenko 2009). Firms need to make provisions for the maintenance of existing equipment or the acquisition of new technology.

Besides, formal finance access remains a critical challenge for small and medium enterprises, particularly in emerging economies (Quartey et al. 2017). Prior research reveals that access to formal or 
traditional credit sources boosts SMEs' productivity by 39 percent (Bah and Fang 2015). Access to these traditional sources of funding, like banks, influences the firm export performance (Abor et al. 2014). Moreover, current literature finds a significant correlation between access to businesses' credit and innovation performance ( $\mathrm{Wu}$ et al. 2016). The effects of severe financial constraints on the firm owner-managers vary. In specific cases, the lack of credit has an attitudinal effect on business owners-managers towards traditional sources of capital (Tolba et al. 2014). The negative perception of entrepreneurs towards formal finance has seen some opt for inefficient informal credit sources, especially in severe credit constraints (Archer et al. 2020). Still, the perception of firm owner-managers is crucial based on their critical decision making role. The government policy framework on financing or supporting small and medium enterprises is essential in addressing entrepreneurial financing challenges (Heshmati 2015). Finance remains a scarce resource that firms must allocate to their most productive and profitable operations.

Nonetheless, owner-managers must devise strategies to make their firms and products competitive-innovation being one approach. The firm has the option of being innovation-orientated, imitation orientation, or both. The firm can also choose and plan how to execute its innovation path, whether on the product, process, organizational, marketing, or varying combinations. That said, sufficient literature examines the impact of innovation on different perspectives of an enterprise. Besides enhancing competitiveness, innovation boosts production efficiency among homogeneous firms (Morris 2018). Still, innovation activities can help the firm survive adverse business tremors in internal or external markets (Ortiz-Villajos and Sotoca 2018). There is a relationship between innovation and export longevity, or the duration the firm stays in specific external markets. Innovative firms and entrepreneurs can still leverage government benefits like tax holidays (Chen and Gupta 2017) and financial support (Bronzini and Piselli 2016). Firms can bank on their innovation capabilities to expand and grow from their domestic markets through export-as an internationalization strategy (Martuscelli and Varela 2018). Through product (service) export, these firms can complement domestic revenue with sales from the external market (Salomon and Shaver 2005).

In Kenya, just like in most emerging economies, there is a consensus on 'SMEs' critical role in the economy (Wang 2016). Governments in these regions formulate different national development policies, plans, and mechanisms to promote technology capacities in industries, including SMEs. Unfortunately, the research and development $(\mathrm{R} \& \mathrm{D})$ budgeted expenditure is always less than one percent of the gross domestic product (GDP). For instance, classified as a lower-middle-income economy, Kenya and the other countries in this category spend 0.58 percent of their R\&D GDP based on the World Bank report, 1996-2018. Besides, the science and technology capabilities are developing, resulting in limited industrial growth and inadequate utilization of domestic capacities and resources. The available numerous foreign supported systems do not always adequately assist local SMEs' technical capacity building. Thus, the primary issue would be to ascertain whether the careful development of domestic policies and mechanisms based on the international support systems can enhance long term capacity building. A technology transfer project is not useful unless it results in firm profitability and growth. In the existing global business environment, local SMEs wishing to gain from foreign technology transfer should not view this as a component of business strategy or separately as a technology project (Kalinga et al. 2010)

Moreover, numerous empirical literature focusing on developing economies highlights the challenges small and medium enterprises face in accessing credit. Central to this is the owners-managers' perception of formal credit availability, whether real or imagined in economies. In the Kenyan case, it is critical to explore the extent to which the perception of hurdles to formal finance by owner-managers is an obstacle to the acquisition of technology by these businesses. The country had introduced the interest capping in 2016, which had the undesired effect of hurting credit access to the private sector. Due to lost risk premium, banking institutions instituted strict business lending policies. Such a move locked out risky businesses from accessing credit. The government repealed the Act of parliament in 2019, but entrepreneurs still complain of a lack of credit access. The Romanian case, 
where firms have challenges accessing credit, mirrors the Kenyan scenario, with the government being a significant player. Anton and Onofrei (2016) show that while the authorities appreciate SMEs' role in creating innovation and employment economic growth in Romania, there is no clear strategy or policy concerning innovative firms' funding or support for high growth firms. Likewise, venture capital, microfinance, crowdfunding, and asset-based finance are alternative funding sources for SMEs but still undeveloped in the country, which government policies may address. SMEs' significance is in developing, and emerging markets; for instance, based on the European Commission (EC), these firms represent 99 percent of all registered businesses in the region. The classification of SMEs differs region by region, and this influences the government policies. While the Kenyan classification of SMEs mirrors that of the EC, the differences lie in the staff or turnover quantification.

Finally, one objective of this study is to provide evidence-based results that can help policymakers pursue the strategic goal of providing a conducive environment that will allow the flow of finance between the credit providers and businesses, mostly regarding the entrepreneurs' perception of formal finance availability. Thus, the study examines how firms plan financially to maintain existing assets and acquire new technology over three years, 2017-2019. Specifically, the authors seek to establish the effect of the capital budget's proportion allocated to acquiring new pieces of equipment (a proxy for new technology) on firm sale performance. The study further explores the role of innovation activities, export, and perception of firm owner-managers towards accessing formal credit. The following section presents a review of recent literature, providing a summary of the existing relevant studies. The section also describes our hypotheses, our methodology used in selecting the study variables for our model, sampling, and the model. Section 3 presents the study's findings, while four presents the relevant discussion of the test results. Section 5 concludes the study with a summary of the results while highlighting limitations.

\section{Materials and Methods}

\subsection{Materials}

Technology is quick, and businesses must maintain the pace to survive in a competitive business environment. For instance, firms must, at present, navigate through the industry 4.0 terrain, whether small, medium, or large. For instance, industry 4.0, or the fourth technological transformation for digital-physical manufacturing systems, spawns a disruptive effect on industries. Manufacturing firms, mostly small and medium-sized ones, face various challenges and continually innovate to remain competitive. One way of innovating is by installing new technologies into firm processes (Yu and Schweisfurth 2020). Still, cost, flexibility, quality, efficiency, and competitive advantage are vital benefits in adopting the latest technology by small and medium enterprises (SMEs). Simultaneously, most SMEs' desire to implement such technologies, but knowledge and financial constraints are critical obstacles Masood and Sonntag (2020). Technology gaps or weakness is one reason why a firm opts to acquire modern technology. While technology acquisition activities vary, it is one-way firms that can experience growth (Robertson 1992). D'Angelo's (2010) study crystallizes the significance of acquired technology by any business. The study concludes that the adoption of output instead of input measures of innovation captures the contribution of technological resources on the firm export performance. Also, product innovations have a positive and significant influence on export performance.

Research suggests that industrial technology acquisition contributes substantially to small and medium enterprises' growth. Due to an intensely competitive environment, firms must continuously innovate to gain from industrial technologies. As technological complexity grows, businesses should develop flexible technology development and knowledge acquisition methods. In Japan, a survey of 407 SMEs found that collaborations and linkages with external stakeholders for industrial technology development and acquisition are essential, particularly in the firm's early growth stages. The results also show that capital and human resources are the primary obstacles to SMEs' efforts in new industrial 
technology development, and these firms were increasingly dependent on external sources of knowledge to shore up their technological competencies (Sugasawa and Liyanage 1999). Still, Lefebvre et al. (1997) show that owners-managers' perception of the external environment is a critical issue for technology policy formulation and its enactment on manufacturing SMEs. That notwithstanding, a more aggressive technology policy results in more significant realized innovative efforts, which are positively related to export performance and, to a lesser extent, to financial performance.

Nonetheless, formal financing remains one of the main hurdles for firms seeking out modern production technologies. Abdul-Hanan (2016) found a relationship between formal credit and technology adoption; credit market inefficiencies can be a significant barrier to adopting yield-enhancing technologies. Existing literature suggests that SMEs form a substantial part of the private sector in most developing and developed economies. Also, there is sufficient evidence showing that small businesses face more considerable constraints when accessing formal external finance, particularly in emerging economies (Beck and Demirguc-Kunt 2006). The development of a financing policy framework is vital to minimize inefficiencies associated with informal sources. Severely financially constrained firms are more active in the informal credit markets than unconstrained and partially constrained (Archer et al. 2020). Authorities have a vital role in ensuring that SMEs have access to formal credit. For instance, a tax advantage (or holidays) for innovative enterprises by the government facilitates their bank credit access. Still, favorable government initiatives can enhance the probability of firms securing bank credit. These initiatives that promote entrepreneurship benefit the younger, smaller, high-growth, and more innovative enterprises, especially those that operate in business environments where the demand and the competition for bank credit are most substantial. Besides, government efforts do not influence the firm's probability of being discouraged from borrowing (Kautonen et al. 2020). Whereas finance availability is critical, firms must exercise caution in their pursuit of credit. For instance, Anton's (2019) analysis of 1105 gazelles (high growth firms) between 2006 and 2014 in central, eastern, and south-eastern reveals that leverage negatively influences firm growth.

The attitude or perception of entrepreneurs or firm managers towards formal credit access may influence their investment decisions. Business failures, mostly small to medium firms, have pushed certain owner-managers or entrepreneurs to be cautious in their financing approach. For instance, in Egypt, Tolba et al. (2014) found a low desire to go for a commercial bank loan while SMEs owner-managers harbor negative perceptions of loan providers' service quality. Moreover, knowledge and subjective norm are the crucial factors which influence loan-taking intentions; these intentions differ based on demography and business characteristics. The low awareness level of owner-managers concerning financial products and procedures affects their attitude significantly. The less knowledge of financing requirements and the dominant role of owner-managers in making business decisions also increase the risk-averse effect on the firm's owner-manager attitude (Rabia and Hafeez 2019). Besides, the opaqueness in providing relevant information by SMEs means banks face information asymmetry, which may cause them to ration credit. Trust, and a good working relationship between firm owners-managers, and credit providers can facilitate formal credit access by bridging the information gap (Kautonen et al. 2020). The role played by foreign-owned banks in the local markets is crucial when firms provide relevant information. Regardless of the firm size, greater availability of information through audited financial statements and a high presence of foreign banks ease credit constraints (Gopalan and Sasidharan 2020)

Further, the perception of owner-managers on the availability of formal credit affects the firm financing plans. For example, in the Chinese situation, the propensity to take the risk and aversion to external control affect SMEs' capital structure. Business owners with better networking ties generally opt for less debt financing by accessing external resources via informal channels (Daniel and Alexander 2012). The role played by the owner-manager is critical since their decisions influence the innovation path or strategy the firm executes (Haddad et al. 2019). Salvador et al. (2020) demonstrate how the acquisition of structural capital (knowledge and information management, organizational structure and culture, systems, and processes) significantly influences 'firms' innovation 
capacity. Wolff and Pett (2006) find that the innovator position and export (internationalization) positively influence new product and process improvements. Also, such a product improvement strategy is positively related to growth and profitability. The firm can opt between an innovation or imitation strategy based on capacity like financial and technical know-how. The enterprise can apply these strategies separately or simultaneously, however, with caution. Lee (2018) argues that technological turbulence has a more positive impact on firm operations based on the level to which a firm is innovation-orientated than imitation-orientated. When the two strategies are adopted independently, each results in positive firm performance. Owner-manager's export commitment, organizational, managerial resources, and capabilities influence export intensity. Of importance, owner-managers perceptions of firm-related barriers negatively affect import exportation intensity (Bianchi and Wickramasekera 2016).

Wang (2016) also explored SMEs from 119 developing countries using data from the World Bank's Enterprise Surveys. Whereas the study concludes that SMEs perceive access to finance as the most critical obstacle that hinders their growth, it finds a significant relationship between the 'firm's access to finance and ownership. High growth firms, those with an annual growth rate of over 25 percent, perceive finance as the biggest hurdle to growth. Thus, consistent with other findings, high growth firms have a higher demand for credit than slow or medium growth firms. Firms in need of external financing cited high-interest rates, collateral requirements, and complex application procedures as the most severe constraints. Small and medium enterprises churn out large volumes of data in their daily operations. The data may be structured or unstructured and is upon the management to extract information that may guide the informed decision-making process. Firms need to start looking inwards for information before moving out. The sieved information may influence operational decisions like the new production technology.

Likewise, being in an era of Big Data (BD), enterprises, especially the small and medium, can turn the same into a competitive advantage — by being innovative. Big Data has significant promises and potentials for SMEs. BD can nurture alliances in firms by providing real-time solutions to problems in every sector. More importantly, a small change in SMEs attributed to BD can have a substantial macro-level impact because of their economic position. Moreover, SMEs are flexible and fast adapt to changes towards efficiency (Sen et al. 2016). Researchers like Ghasemaghaei and Calic (2020) sought to establish the effect of BD's main features (like velocity volume and variety) on innovation performance, which eventually influences firm performance (in areas like financial returns, customer perspective, and operational excellence). BD velocity and variety positively boost the 'enterprise's innovation activities and performance. Whereas large and established firms harness advantages associated with big data, small and medium 'enterprises' response rate is still low. The outcome is promising for SMEs that make efforts to incorporate BD in their innovation programs. For example, in China, Big Data Analytics (predictive and prescriptive) correlates positively with technological innovations (process and product) and 'SMEs' performance (Saleem et al. 2020). That notwithstanding, SMEs encounter several problems and challenges in their adoption of BD for innovation purposes. Based on Korean 'firms' evaluation, Park and Kim's (2019) study highlights specific factors that influence BD's adoption in the innovation processes. These include the benefits of BD, technological capabilities, data quality, integration, and financial investment competence, as the strongest determinants of adoption-management support for big data, privacy and security, and government policy and support are also relevant.

Furthermore, several authors have examined the relationship between innovation strategies and performance. For instance, Gonzalo et al. (2019) evaluation of Mexican SMEs concludes that products, processes, marketing, and management innovation positively impact the business return. In the Chilean market, firms that implement innovation tend to export more than those that do not target and sell in markets that reward innovation. Besides, export markets in which innovative firms outperform non-innovative are those in which innovation results in substantial-quality differences. Innovative firms do not have any advantage by exporting products in target markets that do not compensate for 
innovation (Blyde et al. 2018). The scarcity of resources forces firms to make optimal use of whatever is available. Prior research reveals that scarcity of financial resources positively influences incremental performance in SMEs; to efficient allocation. Therefore, resource-constrained firms, particularly those who struggle with limited finances, must focus on incremental innovation activities instead of radical innovations (Tino et al. 2017). Nevertheless, such findings depend on the market under consideration. For instance, Wang (2019) analysis of firms in emerging economies establishes a positive correlation between radical innovation and performance.

Firm export and innovation activities are intertwined, and it is almost impossible to examine one without the other, particularly in this study: competition and the need to grow the domestic market force some businesses to expand their operations across borders. Moreover, research seems to suggest that there is a difference in performance between exporting and non-exporting firms. An evaluation of Australian manufacturing SMEs establishes that exporting firms boosted their technical efficiency levels over time, which was significantly better than for non-exporter (Le and Valadkhani 2014). By examining the Italian market, D'Angelo (2012) reveals an association between product innovations and sales, with innovative activities positively influencing the 'firms' export intensity. Oura et al. (2016) argue that international experience and innovation capacity are factors associated with the firm internationalization process that involves export activities. Enterprises from developing economies prefer export as an international expansion strategy; this differs from mature markets (Acikdilli et al. 2020). For instance, in the Brazillian context, new exporting firms in the manufacturing industry became more productive and bigger than non-exporters. Still, technological strategies that target innovation improve non-'exporters' and 'exporters' performance (Araújo and Salerno 2015). These firms seem to learn and improve their innovation through exportation; the Brazillian findings concur with a similar study on firms in the United Kingdom (Love and Ganotakis 2013).

What emerges from the literature review is that there is a nexus between technology adoption and financial performance. By their nature, SMEs are herald as centers of change due to large companies' rigidity in implementing innovative programs. New technology acquisition depends not only on the firm's policy regarding technology but also on the owner-managers perception of the availability of formal credit. Most importantly, the perception depends on an individual and could be real or imagined; however, this ultimately influences capital budget decisions. Besides, whereas technology allows firms to be innovative and thus competitive, research does not always establish a superior financial performance (sales in the local and export market) for innovative firms than non-innovative firms. The firm may also opt to be innovation-orientated by developing new products unique to the market or non-innovative by copying or imitating what is done by other industry players. Regardless of the strategy, it must budget for the adoption and implementation of the relevant technology. The current study examines the interplay between technology acquisition and financial performance based on other factors like owner-managers perception of traditional finance availability (and by extension, technology policy), innovation activities, and export longevity. Discussions on the relevant findings of the study variable are in the subsequent sections. Most importantly, the research focuses on emerging economies with particular emphasis on the Kenyan context.

Figure 1 presents the conceptual and statistical framework guiding the study. There are two paths in the model, the conditioned [a] path (with owners-managers of formal financing availability moderating the predictor factor and mediating variables) and the unconditioned $[b]$ path (between the mediators and the outcome variable). The predictor factor has three different effects on sales, the direct, indirect, and total effect based on the model. Three hypotheses, the conceptual and strategic framework, summarize these relationships.

Hypothesis 1 (H1). Proactive strategies in acquiring new technology (as a proportion of the capital budget) affect sales significantly (no mediation or moderation). 
Hypothesis 2 (H2). The innovation activities mediate the correlation between the capital budget's proportion to acquire new technology and sales proactively; however, when moderated by the perceptions owner-managers have towards formal credit accessibility, such a relationship fails to hold.

Hypothesis 3 (H3). The relationship between proactive acquisition of new technology (as a fraction of the capital budget) and sales as mediated by export longevity is robust more so when moderated by the perceptions firm owners, or managers have towards formal financing availability.

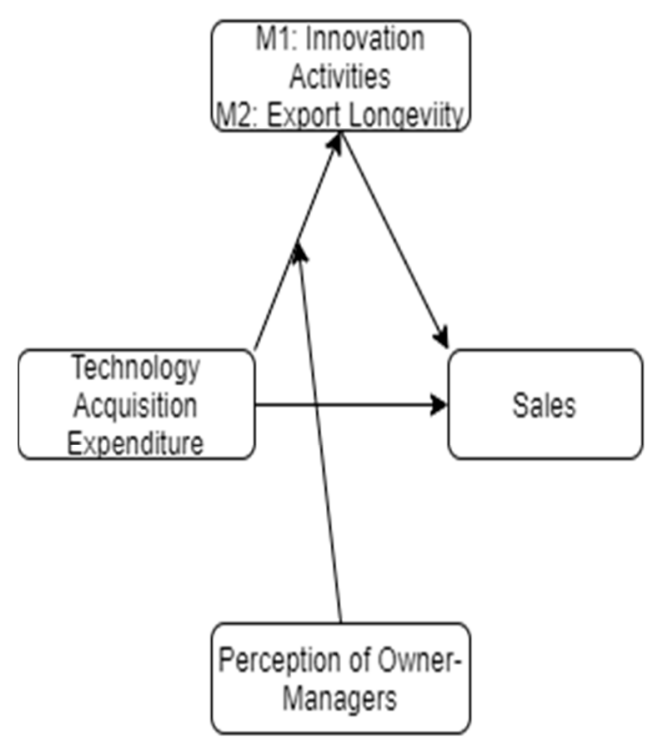

\section{A}

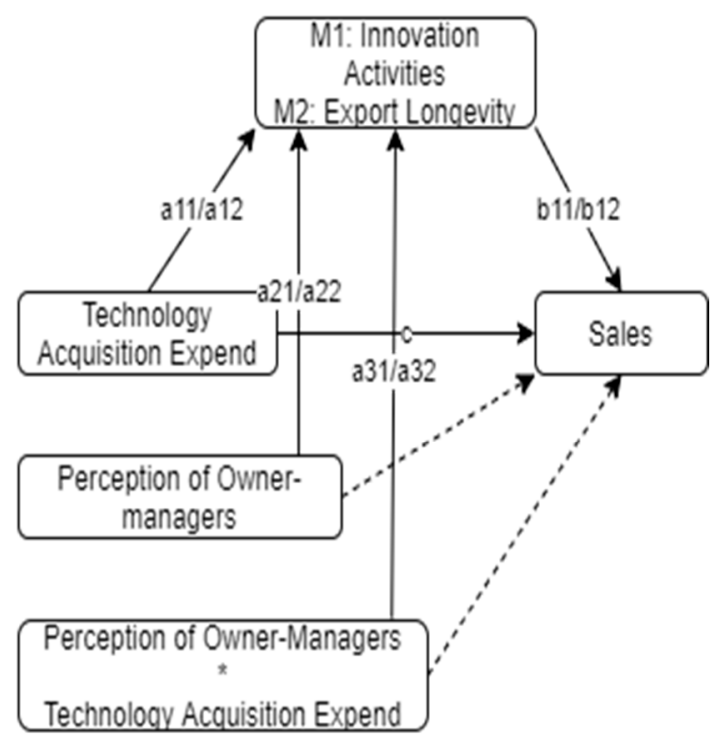

$B$

Figure 1. Conceptual (A) and statistical (B) frameworks.

\subsection{Methods}

- Sampling Framework

Our study draws on country-wide data with the choice based on research objectives. Our analysis draws on data obtained through a survey that focuses on the correlation between technology acquisition and financial performance mediated by innovation activities and export longevity. In particular, we examine the owners-managers' role perception of formal finance availability, which may be real or imaginary. We believe there is a correlation between real barriers to formal finance and the perception of barriers that affect firm performance through financing decisions like technology acquisition, innovation, and exportation through the survey. The survey brought about a useful series of study variables for exploring the perceived obstacles of firm financing, its operations, and performance. Before proceeding further, it is paramount to highlight relevant methodological issues about the definition of concepts and variable quantification, as shown in Table 1. The variables "technology acquisition," "owner-managers perception," "innovation-activities," and "export-longevity" represent the predictor, moderator, and mediator variables. The variable selection was arbitrary, but it reflects our grasp of the most frequently examined firm access to credit and its effect on innovative firms' performance.

The sample frame consists of 500 small and medium enterprises that sell locally and export their products and services-selected from the Kenya Business Directory, published by African Pages with over 52,000 firms. The selected firms cut across different economic sectors, either in manufacturing, service, or both sectors. Kenya comprises primarily of eight geographic regions, and these formed the sampling cluster. To choose the firms to be surveyed per cluster, we employed a simple random 
sampling technique. Between February and August 2020, data collection was done mainly through emails and a few hard copies. The research instrument was still tested by sharing it across ten working university doctorate candidates, mainly in managerial positions. Their feedback improved the efficiency of the questionnaire in collecting the desired data. The researchers targeted senior managers while observing a variety of job titles. The respondents included managers in finance, sales, operations, strategic business units, innovation, or Research and Development departments. Email reminders and telephone calls were possible generated 101 useable questionnaires, 20.2 percent (of the 500 emailed questionnaires). The sample size approximates previous studies touching on innovation and export as some of the study variables. For instance, (Yacine et al. 2018) evaluated the export performance of small and medium enterprises in the developing economies, specifically Algeria, and used a sample size of 103 firms. More precisely, Zisuh (2018) analysis of Cameroonian Cocoa export firms used the same sample size as the present study, 101.

\section{- $\quad$ Measurement}

Table 2 shows the measurement and quantification of the study variables. More specifically, both sales and new technology acquisition are proportioned. For sales, the respondents indicated the percentage change in sales, whether positive or negative, over the study period. Other previous studies used sales to measure financial performance when evaluating the effect of innovation include Lara (2015) and Rodil et al. (2016). The respondents indicated the capital budget's proportion meant for acquiring new machinery or new technology. On the perception of owner-managers about the availability of funding or access to credit services, the respondents had two categorical options. The firm either encountered no hurdles in its attempts to secure financial resources or if it did, the obstacles were significant. In particular, the perception of owner-managers about the availability of funding or lack of it focused on formal institutions like banks. The export longevity duration in years or months (fraction) the business has exported its products/services. Innovation falls into four categories, namely, product, process, organizational, and marketing. About the four categories, the innovation-activities variable mirrors the third Community Innovation Survey (CIS) questionnaire. In particular, the survey breaks down the four types of innovation into twelve subgroups that enable the respondents to understand and respond appropriately or clearly. Thus, the level of innovation activity varied across the firms depending on the number of activities undertaken. Besides, the CIS is a popular tool used in the survey of innovation activities in enterprises and adopted by Eurostat.

\section{- Measurement Model Validation}

Data were analyzed by Process Macro version 3.5 through SPSS version 25. The selected ordinary least square (OLS) method allowed for the moderated mediation analysis. Together, moderation and mediation analysis are commonly known as conditional process models since the process through which a predictor affects an outcome is conditional on another variable (Hayes 2015). Moderated mediation analysis helps establish whether the magnitude of the mediated effect changes as a function of a moderating variable (Preacher and Hayes 2008; Hayes 2009). The moderated mediation allowed the researchers to examine the indirect conditional effect of the capital budget's proportion for technology acquisition on sales performance. Mathematically, the conditional model consists of two paths, the moderated path $[X \rightarrow M]$, and the mediated path $[X \rightarrow M \rightarrow Y]$, as shown below:

$$
\begin{gathered}
\mathrm{M}_{1}=i_{m 1}+a_{1} X+a_{2} W+a_{3} X W+e_{m}, \\
\mathrm{M}_{2}=i_{m 2}+a_{1} X+a_{2} W+a_{3} X W+e_{m}, \\
\gamma=i_{y}+c^{\prime} X+b_{1} \mathrm{M} 1+b_{2} \mathrm{M} 2+e_{y},
\end{gathered}
$$


where $C^{\prime} X$ denotes the direct (not indirect) influence of the predictor variable on the outcome variable, $\left[a_{i j}\right]$ the regression coefficients, $X W$, predictor and mediator variables, while $\left[b_{i j}\right]$ regression coefficients of the unconditioned path. The indirect effect of the moderator on the outcome variables is:

$$
\theta_{m \rightarrow y}=a_{1}+a_{3} W
$$

The indirect effect of $X$ on $Y$ is a product of $X$ on $M\left[\theta_{X \rightarrow M}=a_{1}+a_{3} W\right]$ and the effect of $M$ on $Y$ $[b=X \rightarrow M]:$

$$
\begin{gathered}
b\left(\theta_{X \rightarrow M}\right)=b_{1}\left(a_{11}+a_{31} W\right)+b_{2}\left(a_{21}+a_{31} W\right) \\
\gamma=i_{y}+c^{\prime} X+b M .
\end{gathered}
$$

\begin{tabular}{|c|c|}
\hline Variable & Quantification \\
\hline Sales Change $(Y)$ & $\begin{array}{l}\text { Percentage change in sales volume, whether positive or negative, over the } \\
\text { three years. }\end{array}$ \\
\hline Export Duration (M1) & $\begin{array}{l}\text { The number of years (or months as a fraction) the firm has been selling its } \\
\text { products externally. }\end{array}$ \\
\hline Technology Acquisition (X) & $\begin{array}{l}\text { The proportion or percentage of capital budget meant for acquiring new } \\
\text { (technology) machinery or upgrading the firm's existing ones. }\end{array}$ \\
\hline Owner-Managers Perception (W) & $\begin{array}{l}\text { The perception of owner-managers on the accessibility of formal finance } \\
\text { where the firm either (a) perceived no obstructions in accessing funding } \\
\text { coded " } 0 \text { " or (b) perceived significant obstructions in accessing formal } \\
\text { finance, coded " } 1 \text { ". }\end{array}$ \\
\hline Innovation Activities (M2) & $\begin{array}{l}\text { The firm implements one or more of the following activities: (a) Goods } \\
\text { innovation (New or significantly improved goods; this excludes the simple } \\
\text { resale of new products and changes which are entirely aesthetic); (b) Service } \\
\text { innovation (New or substantially improved services; (c) New or } \\
\text { substantially improved methods for producing goods and or services; } \\
\text { (d) New or substantially improved logistics, distribution or delivery } \\
\text { methods for the 'firms' goods and or services; (e) New or substantially } \\
\text { enhanced supporting activities for the 'firm's process like maintained } \\
\text { systems or in areas like purchasing, computing, or accounting; (f) New } \\
\text { business practices relating to organizing procedures (for instance the first } \\
\text { use of business re-engineering, quality management, lean management, } \\
\text { supply chain management among others; (g) New methods of organizing } \\
\text { task responsibilities and decision making like decentralization, integration, } \\
\text { training, etc.; (h) New methods of organizing external relations with other } \\
\text { partners such as first use of partnerships, alliances, outsourcing etc.; } \\
\text { (i) Substantial changes to the packaging of goods or services or aesthetic } \\
\text { design; (j) New technique or media for product promotion like first time } \\
\text { introduction of customer loyalty system, use of new advertising channel } \\
\text { etc.; (k) New sale channels or product sales like first time use of } \\
\text { franchise/distribution, product presentation etc.; (l) New approaches to } \\
\text { pricing goods or services like first time introduction of discount systems, } \\
\text { demand variable pricing etc. }\end{array}$ \\
\hline
\end{tabular}

Table 1. Measurement and scaling of the variables. 
Table 2. Descriptive statistics (normalized) and correlation matrix.

\begin{tabular}{|c|c|c|c|c|c|c|c|c|c|}
\hline Variable & $\begin{array}{l}\text { Max } \\
\text { Stat }\end{array}$ & $\begin{array}{l}\text { Mean } \\
\text { Stat }\end{array}$ & $\begin{array}{l}\text { Standard } \\
\text { Deviation }\end{array}$ & $\begin{array}{l}\text { Variance } \\
\text { Inflation } \\
\text { Factor }\end{array}$ & $\begin{array}{c}\text { Sales } \\
\text { (Change) }\end{array}$ & $\begin{array}{l}\text { Technology } \\
\text { Acquisition }\end{array}$ & $\begin{array}{c}\text { Innovation } \\
\text { Activities }\end{array}$ & $\begin{array}{l}\text { Owners- } \\
\text { Managers } \\
\text { Perception }\end{array}$ & $\begin{array}{c}\text { Export } \\
\text { Longevity }\end{array}$ \\
\hline $\begin{array}{c}\text { Sales } \\
\text { (Change) }\end{array}$ & 2.11 & 0.463 & 0.63919 & & 1 & 0.64 & -0.01 & -0.177 & 0.534 \\
\hline $\begin{array}{l}\text { Technology } \\
\text { Acquisition }\end{array}$ & 2.15 & 0.473 & 0.64 & 1.262 & 0.64 & 1 & 0.144 & -0.026 & 0.451 \\
\hline $\begin{array}{l}\text { Owners- } \\
\text { Managers } \\
\text { Perception }\end{array}$ & 1 & 0.43 & 0.497 & 1.049 & -0.177 & -0.026 & -0.195 & 1 & 0.042 \\
\hline $\begin{array}{c}\text { Export } \\
\text { Longevity }\end{array}$ & 18.53 & 11.2 & 3.42145 & 1.302 & 0.534 & 0.451 & 0.209 & 0.042 & 1 \\
\hline
\end{tabular}

The correlation matrix on the diagonal.

\section{Results}

Table 2 shows descriptive statistics and the correlation matrix of the study variable. The Process Macro inbuilt tools allowed the fulfillment of specific OLS regression requirements. For instance, the HC4 option automatically addressed any heteroscedasticity in the data. Mean-centering addressed (multi) collinearity, an essential step in moderation analysis (Dalal and Zickar 2011). Thus, mean-centering handled any unforeseen multicollinearity between the variables and interactions. Besides, the variance inflation factor (VIF) is within acceptable limits. The average growth in sales closely mirrors the change in the capital 'budget's proportion spent on new technology,-4.67 percent and 4.73 percent. On average, analyzed firms implemented at least two innovation-related activities on average. Still, the duration these firms have been exporting averaged eleven years, which is hardly surprising. The East African Common (EAC) common market in existence for over 20 years and comprises six member states, offers an enormous market to investors. Being the most developed economy in the region, businesses in Kenya have seized economic block opportunities. The export longevity is the only variable that correlates positively with all other factors.

Table 3 presents the ordinary least square regression results with all variables mean-centered except owner-managers' perception of formal financing access. Regression coefficients $\left[\sigma_{11}\right]$ and $\left[\sigma_{12}\right]$ represent the direct correlation between the predictor factor and the two mediating variables. The effect of the capital 'budget's proportion spent on acquiring new technology on the two mediators (M1\&M2) is significant. The planned expenditure relates positively to the two mediators and is statistically significant as there is no zero within the confidence interval boundaries-to innovation-related activities $\left(\left(\sigma_{11}=1.2603 ; 0.4360,2.0846\right)\right.$ and export longevity $\left(\left(\sigma_{12}=2.6808 ; 1.8675,3.4943\right)\right.$. The regression coefficients $\left[\sigma_{21}\right]$ and $\left[\sigma_{21}\right]$ estimate the perception of the owner-investors' effect on the innovation-related activities and export longevity when there is no allocation for new technology acquisition in the capital budget. Perception affects innovation negatively, but this is not statistically different from zero $\left(\left(\sigma_{21}=-0.40590 .4059 ;-1.1921,0.3804\right)\right.$. Still, the owners-investors perception of the availability of formal credit positively influences export longevity; however, the relationship remains statistically insignificant $\left(\sigma_{22}=0.0732 ;-1.0959,1.2423\right)$. 
Table 3. Ordinary least squares regression results of the moderated mediated model (continuous variables mean-centered).

\begin{tabular}{|c|c|c|c|c|c|c|}
\hline & & & & Outcome & & \\
\hline & & $\begin{array}{l}\text { Innovation-Related } \\
\text { Activities (M1) }\end{array}$ & & Export Longevity (M2) & & Change in Sales $(Y)$ \\
\hline Variable & $\begin{array}{l}\text { Coefficient; Standard } \\
\text { Error }\left(\mathrm{SE}_{\text {boot }}\right)\end{array}$ & 95\% Bootstrap CI & $\begin{array}{l}\text { Coefficient; } \\
\text { Standard Error }\end{array}$ & 95\% Bootstrap CI & $\begin{array}{l}\text { Coefficient; Standard } \\
\text { Error }\left(\mathrm{SE}_{\text {boot }}\right)\end{array}$ & 95\% Boots CI \\
\hline Intercept & $\sigma_{1} \rightarrow 2.1149(0.2715)$ & $\sigma_{2} \rightarrow 1.5761,2.6537$ & $10.8193(0.4571)$ & $9.9121,11.7265$ & $\sigma_{3} \rightarrow-0.2352(0.1955)$ & $-0.6233 \rightarrow 0.1529$ \\
\hline $\begin{array}{l}\text { X: Technology } \\
\text { Acquisition }\end{array}$ & $\sigma_{11} \rightarrow 1.2603(0.4153)$ & $0.4360,2.0846$ & $\sigma_{12} \rightarrow 2.6808(0.4099)$ & $1.8675,3.4943$ & $c^{\prime} \rightarrow 0.9893(0.1542)$ & $0.6832 \rightarrow 1.2954$ \\
\hline $\begin{array}{l}\text { W: Perception of } \\
\text { Owner-Managers }\end{array}$ & $\sigma_{21} \rightarrow-0.4059(0.3962)$ & $-1.1921,0.3804$ & $\sigma_{22} \rightarrow 0.0732(0.5891)$ & $-1.0959,1.2423$ & & \\
\hline $\begin{array}{l}\text { XW: Technology Acq } \times \\
\text { Perception }\end{array}$ & $\sigma_{31} \rightarrow-2.6999(0.7813)$ & $-4.2506,-1.1492$ & $\sigma_{32} \rightarrow-4.4309(0.8725)$ & $-6.1626,-2.6992$ & & \\
\hline M1: Innovation-Activities & & & & & $\beta_{1} \rightarrow-0.1657(0.0436)$ & $-0.2523 \rightarrow-0.0791$ \\
\hline \multirow[t]{4}{*}{ M2: Export Longevity } & & & & & $\beta_{2} \rightarrow 0.1066(0.0204)$ & $0.0661 \rightarrow 0.1471$ \\
\hline & $R^{2} \rightarrow$ & 0.206 & & $\rightarrow 0.299$ & $\rightarrow 0.6745$ & \\
\hline & & & $\begin{array}{l}\text { Index of Moderated } \\
\text { Mediation }\end{array}$ & & & \\
\hline & Mediator: & & & & & \\
\hline \multirow[t]{2}{*}{$\begin{array}{l}\text { Perception of } \\
\text { Owner-Managers }\end{array}$} & $\begin{array}{l}\text { M1: Innovation } \\
\text { Activities }\end{array}$ & $a_{41} b$ & $0.4473(0.1275)$ & $0.1772 \rightarrow 0.6780$ & & \\
\hline & M2: Export Duration & $a_{42} b$ & $-0.4723(0.1287)$ & $-0.7051 \rightarrow-0.1922$ & & \\
\hline
\end{tabular}

Percentile bootstrap confidence interval (CI) based on 5000 bootstrap samples at $95 \%$ bias-corrected bootstrapped confidence interval. (SEboot) = bootstrapped standard error. All continuous variables are mean-centered (allocated towards the acquisition of technology) the indirect effect on sales through the two mediators. The index of moderated mediation of such expenditure through M1 (innovation activities) is statistically significant and positive $\left(a_{41} b=0.4473 ; 0.1772,0.6780\right)$. Based on this index, the second hypothesis H2: The innovation activities mediate the correlation between the capital 'budget's proportion to proactively acquiring new technology and sales; nonetheless, when moderated by the perceptions of owner-managers towards formal credit accessibility, such a relationship fails to hold. Therefore, the hypothesis fails to hold or is unconfirmed. 
Regression coefficients $\left[\sigma_{31}\right]$ and $\left[\sigma_{32}\right]$ estimate the conditional effect of the predictor variable on the two mediators, as shown by the interaction term XW. The capital 'budget's proportion planned for new technology acquisition negatively affects innovation-related programs and export longevity, but this is not contingent on the owner-managers perception of the formal finance availability. That is for innovation $\left(\sigma_{31}=-2.6999 ;-4.2506,-1.1492\right)$ and export longevity $\left(\sigma_{32}=-4.4309 ;-6.1626,-2.6992\right)$. Nonetheless, the capital budget's proportion of new technology acquisition total effect accounts for 20.6 percent of the variance in the level of innovation-related activities and 29.9 percent for export longevity. The regression coefficients $\left[\beta_{2}\right]$ and $\left[\beta_{2}\right]$ represent the unconditioned path and, in particular, examine the effect of the mediators on the outcome variable when there is no allocation for the acquisition of new technology in the capital budget. The firm's level of innovation activities in the absence of budgetary allocation, as suggested, negatively influences sales performance, but this is statistically insignificant $\left(\beta_{1}=-0.1657 ;-0.2523,-0.0791\right)$. Nonetheless, while holding zero budget for new technology acquisition, export longevity relates positively to sale performance; and this is statistically different from zero.

The capital 'budget's proportion allocated for the acquisition of new technology positively and significantly affects sales performance $\left(c^{\prime}=0.9893 ; 0.6832,1.2954\right)$-path $[c \prime X]$. The predictor variable total effect accounts for 67.45 percent of the change in sales performance. The findings confirm the first hypothesis; (H1) Proactive strategies in acquiring new technology (as a proportion of the capital budget) influence sales. Besides, $a_{41} b$ and $a_{42} b$ are the indices of moderated mediation of $X^{\prime} s$ (the capital budget's proportion meant for acquisition of new technology) indirect influence on $Y$ (sales) by the mediators, M1\&M2. The indices represent the effect of the predictor on the outcome variable conditioned on the moderator. These indices quantify the relationship between owner-'managers' perception (concerning traditional financing) and the capital 'budget's portion.

Nonetheless, for the second mediator, M2, export longevity, the index of moderated mediation is negative and insignificant $\left(a_{42} b=-0.4723 ;-0.7051,-0.1922\right)$. However, the index's insignificance does not mean the complete absence of moderated mediation (Hayes 2018). The third hypothesis; (H3: The relationship between proactive acquisition of new technology (as a fraction of the capital budget) and sales as mediated by export longevity is robust more so when moderated by the perceptions firm owners or managers have towards formal financing availability) also fails to be confirmed. That is, the perception of business owners or managers about access to institutionalized credit does not moderate the relationship between the capital budget's expenditure for the acquisition of new technology and sales as mediated by export longevity. In a nutshell, there is no moderated mediation in the second mediation path, with export longevity as the mediator.

Mathematically, the effect of technology acquisition on innovation-related activities or export longevity $\left[\theta_{X \rightarrow M}\right]$ illustrated by Equations (1) and (2) is:

For innovation-related activities:

$$
\mathrm{M}_{1}=2.1149+1.2603 X-0.4059 W-2.6999 X W .
$$

For export longevity:

$$
\mathrm{M}_{2}=10.8193+2.6808 X+0.0732 W-4.4309 X W .
$$

Based on Equations (4) and (5), the indirect effect of technology acquisition on sales performance:

$$
\begin{gathered}
b\left(\theta_{X \rightarrow M}\right)=[-0.1657(2.1149-0.4059 W)]+[0.1066(10.8193-4.4309 W)] \\
\left.b\left(\theta_{X \rightarrow M}\right)=(-0.3504+0.0067 W)+(1.1533-0.4723 W)\right] \\
b\left(\theta_{X \rightarrow M}\right)=0.8029-4.4242 W .
\end{gathered}
$$


From Equation (3), the total effect of new technology acquisition on sales performance is:

$$
Y=0.2352+0.9893 \mathrm{X}-0.1657 \mathrm{M} 1+0.1066 \mathrm{M} 2
$$

Inserting owner-manager perception values into the OLS models above yields the effects of capital 'budget's proportion for the acquisition of new technology on sale performance among firms.

\section{Discussion}

The results reveal a direct, positive, and significant relationship between the capital budget percentage for acquiring new technology and innovation activities. In other words, such acquisitions allow firms to enhance their level of innovation programs. The perceptions firm owner-managers have concerning access to external formal funding sources remain critical in implementing innovation strategies. The relevant government institutions must develop policies and structures that address any negative sentiments towards formal funding access. As Wellalage and Fernandez (2019) argue, in emerging economies, the policy framework on external financing is critical for firms seeking to improve their innovation activities, mainly for small and medium enterprises. Besides, medium-to-long-term maturity loan facilities offered by institutionalized credit providers should allow innovative firms or entrepreneurs to enjoy a more extended repayment period; which, encourages a positive relationship between firm-level innovation activities and traditional financing. Still, prior literature suggests that the firms' use of formal credit and their innovativeness foster growth (Ullah 2019). Granted, access to formal funding allows firms to apportion substantial amounts of their capital budgets to acquire expensive technology.

Nevertheless, while owners-manager perception concerning formal finance does not significantly influence innovation activities and export longevity, it should be construed to mean zero influence. Existing literature suggests that access to formal credit substantially influences firms' export activities (Abor et al. 2014). One of the challenges small and medium enterprises grapple with is access to affordable formal financing. Additionally, extensive research shows that SMEs face more considerable growth constraints due to reduced access to traditional external funding sources. Financial and institutional advancement help minimize SMEs' growth constraints by improving their access to external funding leveling the playing field among firms of different sizes (Beck and Demirguc-Kunt 2006). For instance, in Kenya, data from the Kenya National Bureau of Statistics show that over fifty percent of the start-ups are never operational beyond their first anniversary. Entrepreneurs have continually complained of facing severe hurdles in accessing formal financing, partly due to some 'ventures' riskiness. Besides, the collateral terms demanded by financial institutions is often beyond what most infant and start-ups can provide. Such a situation demotivates potential and current entrepreneurs from pursuing formal financing; the government has not been better either, but it has to develop the right business financing policy frameworks.

Moreover, the capital budget's planned expenditure for acquiring new technology affects enterprise export longevity. New technology enhances 'firms' innovativeness, with the end product being a boost in their competitive advantage. Dai et al.'s (2020) findings support the present study results by demonstrating that innovative firms (by acquiring technology) survived longer in the export market. Competition in the external markets means that domestic firms must always reevaluate their strategies. In particular, Dai et al. (2018) examine the vital role competition plays in offering innovation incentives. Their findings illustrate that competition ensures exporters enhance innovation activities compared to non-exporters. Additionally, the new product development expenditure of exporters grew more than that of non-exporters. The forces of demand and supply in an open economy means that businesses must continuously produce quality products at the least cost possible.

The first hypothesis test results show a substantially positive linear correlation between the capital budget's proportion for acquiring new technology and the sale. This relationship's linearity nature suggests that firm owner-managers can expect positive change in their sales performance based on 
the proportion of the capital 'budget's expenditure to acquire new technology or upgrade. Further, desirable sales revenue streams in the domestic market are complement by external sales for exporters. Our findings concur with the study by Schwager et al. (2000), who demonstrated the positive nature of the relationship between technological resource acquisition and financial performance. Besides, the new technology acquisition has a desirable effect on firms' innovation performance (Sun 2014); as seen earlier, such performance ultimately affects sales. Saji and Mishra (2012), however, succulently summarizes the first hypothesis of this study - by establishing a correlation between technology acquisition and enterprise-level performance, positively mediated by new product (innovation) commercialization.

In the final model, innovation activities correlate negatively with sales, but this is statistically insignificant. That is, firms should only focus on the number of innovation activities, whether in the product, process, organizational, or marketing, for which they have sufficient capacity. Implementing many innovation-related activities with limited resources will stretch the available facilities to the limit, a fact that innovation or strategic business units directors should consider. Overutilization of the available capacity may not necessarily negatively affect sales but may slow its desired growth. As one of the resources, finance has consistently hurt the innovation activities of financially constrained small and medium firms, more so those in emerging markets (Song et al. 2015). Start-ups must allocate their resources in prioritized or profitable areas of their operations at the infancy stage. Models exist on firms' optimal resource allocation; however, small firms with limited financial resources should consider those based on cost (Dehnokhalaji et al. 2017).

Furthermore, export longevity influences sales positively and significantly. Increasing competition in the domestic market should stimulate businesses to grow their operations across borders. The probability of exiting from export markets tends to decrease over the export duration. The export experience and innovation play a significant role in determining continued operation in foreign markets. In particular, the probability of exiting these markets is often lower for firms engaging more in R\&D activities both before and after starting exportation. Thus, firms manufacturing differentiated products have a greater incentive to make investments before export commencement, and these investments are another reason for export longevity in external markets (Inui et al. 2017). In the African context, Babatunde (2017) shows that access to credit, capital intensity, and ownership or managerial skills, factors related to the present study, determine export intensity. Salomon and Shaver (2005) find a substantial correlation between export and domestic sales of the firm. Exporting enterprises concentrate on the domestic market as the strength in this market drives up their export sales. Increased sales in one market can reduce SMEs' financial constraints by facilitating funding for firm development in the export market (Bardaji et al. 2019).

The index of moderated mediation offers some useful lessons for business owner owners or decision-makers. Based on the second hypothesis's test result, there is evidence of moderated mediation concerning the firm's first mediator (number of) innovation activities. Thus, the indirect effect of the capital budget's expenditure on acquiring new technology on sales as conditioned on the perception of firm owner-managers about access to formal finance is significant. In other words, the perception of entrepreneurs and firm managers towards access formal finance substantially moderates the mediated (by innovation) relationship between the proportion of their capital budgets spent on acquiring new technology and change in sales. The perception of firm owner-managers concerning the availability of traditional financing is psychological and subjective. The lack of objectivity, clarity, and information can result in the firm missing on opportunities when owner-managers opt not to seek traditional financing. Those tasked with making critical decisions with substantial impact on firm operations must decipher the economic conditions well, especially financing. The study findings show that investment in new equipment, innovation activities, and exportation significantly influence sales performance. Should these decision-makers make the wrong assumption on credit availability, their firms may lose specific investment opportunities. The negative perception of owner-managers probably explains why the variable influences negatively innovation activities. In a nutshell, owner-managers' positive attitude 
can substantially alter sales performance as it affects critical decisions on financing, new technology adoption, the level of innovation activities undertaken, and further expansion of exports.

Finally, the findings of this study concur and contradict the findings by other scholars. As already mentioned elsewhere, the Kenyan economy has its uniqueness. However, the findings on the perception of financing hurdles by owner-managers are in tandem with Wang's (2016) study. On the same note, Cobham's (1999) analysis of southern European SMEs established that support for highly successful firms is distinctly different from struggling businesses. Besides, policies that encourage banking efficiency and stimulate venture capital investment influence SMEs' investment in technology differently. Most importantly, Cobham concludes that finance determines the level and the nature of technology investment by these firms- the conclusion mirrors the findings of the present study based on the bootstrap confidence interval of the index of moderated-mediation, which does not straddle a zero.

\section{Conclusions}

The study sought to examine the effect of the capital budget on acquiring new technology on sales. The test results reveal a significantly positive relationship between the capital's budget for acquiring new technology and sales; this confirmed the first hypothesis. The perception of firm owner-managers about the accessibility to traditional financing plays a critical role in innovation activities. Either way, the firm owner-managers' mindset, attitude, or perception about financing will affect firm operations, either positively or negatively. While implementing innovation activities, firms must only implement those programs for which they have adequate capacity. The duration the firm has been exporting its products correlates positively with the change in sales. Thus, innovation programs play a critical role in export longevity and firm sale performance. Besides, the test rest establishes evidence of a moderated mediated relationship between the capital budget's proportion for new technology acquisition and sales performance, which also confirms the second hypothesis. The third hypothesis, nonetheless, was unconfirmed. Future studies may evaluate the correlation between the study variables by checking the effect of firm size and or age. Further, these may interrogate the negative correlation between firm owner-managers' perception of traditional financing and innovation activities and or export. Nevertheless, as is the case with similar studies, there may be limitations to our study. Quantifying and demystifying real against perceived perceptions of formal finance availability obstacles may not be as easy as researchers like Doern (2009) questioned. The process is psychological, although we used approaches used previously to capture such perceptions. Nonetheless, we feel the study's results are consistent with the findings of studies in other economies.

Author Contributions: Conceptualization, E.M.; methodology, E.M.; software, E.M.; validation, E.M., C.W., and Z.Z.; formal analysis, E.M.; investigation, C.W.; resources, Z.Z.; data curation, C.W.; writing-original draft preparation, E.M.; writing-review and editing, C.W.; visualization, C.W.; supervision, Z.Z.; project administration, Z.Z.; funding acquisition, Z.Z. All authors have read and agreed to the published version of the manuscript.

Funding: This research received no external funding.

Acknowledgments: The researchers acknowledge the support given by Szent Istvan University, School of Economics, and Regional Science through administrative and technical support.

Conflicts of Interest: The authors declare no conflict of interest.

\section{References}

Abdul-Hanan, Abdallah. 2016. Does Credit Market Inefficiency Affect Technology Adoption? Evidence from Sub-Saharan Africa. Agricultural Finance Review 76: 494-511. [CrossRef]

Abor, Joshua Yindenaba, Elikplimi Komla Agbloyor, and Ransome Kuipo. 2014. Bank Finance and Export Activities of Small and Medium Enterprises. Review of Development Finance 4: 97-103. [CrossRef]

Acikdilli, Gaye, Alma Mintu-Wimsatt, Ali Kara, and John E. Spillan. 2020. Export Market Orientation, Marketing Capabilities, and Export Performance of SMEs in an Emerging Market: A Resource-Based Approach. Journal of Marketing Theory and Practice, 1-16. [CrossRef] 
Anton, Sorin Gabriel. 2019. Leverage and Firm Growth: An Empirical Investigation of Gazelles from Emerging Europe. International Entrepreneurship and Management Journal 15: 209-32. [CrossRef]

Anton, Sorin Gabriel, and Mihaela Onofrei. 2016. Public Policies to Support Entrepreneurship and SMEs. Empirical Evidence from Romania. Transylvanian Review of Administrative Sciences 12: 5-19.

Araújo, Bruno César, and Mario Sergio Salerno. 2015. Technological Strategies and Learning-by-Exporting: The Case of Brazilian Manufacturing Firms, 2006-2008. International Business Review 24: 725-38. [CrossRef]

Archer, Lan, Parmendra Sharma, and Jen-Je Su. 2020. SME Credit Constraints and Access to Informal Credit Markets in Vietnam. International Journal of Social Economics 47: 787-807. [CrossRef]

Babatunde, Musibau Adetunji. 2017. Export Propensity and Intensity of Nigerian SMEs. Journal of Small Business E Entrepreneurship 29: 25-55. [CrossRef]

Bah, El-hadj, and Lei Fang. 2015. Impact of the Business Environment on Output and Productivity in Africa. Journal of Development Economics 114: 159-71. [CrossRef]

Bardaji, José, Jean-Charles Bricongne, Benoît Campagne, and Guillaume Gaulier. 2019. Domestic and Export Performances of French Firms. The World Economy 42: 785-817. [CrossRef]

Beck, Thorsten, and Asli Demirguc-Kunt. 2006. Small and Medium-Size Enterprises: Access to Finance as a Growth Constraint. Journal of Banking and Finance 30: 2931-43. [CrossRef]

Bianchi, Constanza, and Rumintha Wickramasekera. 2016. Antecedents of SME Export Intensity in a Latin American Market. Journal of Business Research 69: 4368-76. [CrossRef]

Blyde, Juan, Gonzalo Iberti, and Micaela Mussini. 2018. When Does Innovation Matter for Exporting? Empirical Economics 54: 1653-71. [CrossRef]

Bronzini, Raffaello, and Paolo Piselli. 2016. The Impact of R\&D Subsidies on Firm Innovation. Research Policy 45: 442-57. [CrossRef]

Chen, Ming Chin, and Sanjay Gupta. 2017. The Incentive Effects of R\&D Tax Credits: An Empirical Examination in an Emerging Economy. Journal of Contemporary Accounting and Economics 13: 52-68. [CrossRef]

Cobham, Alexander. 1999. The Financing and Technology Decisions of SMEs: I. Finance as a Determinant of Investment. QEH Working Paper Series 24; Oxford: Queen Elizabeth House, University of Oxford, pp. 1-37.

D'Angelo, Alfredo. 2010. Technological Resources, External Research Partners, and Export Performance: A Study of Italian High-Tech SMEs. In Reshaping the Boundaries of the Firm in an Era of Global Interdependence (Progress in International Business Research). Edited by José Pla-Barber and Joaquín Alegre. Bingley: Emerald Group Publishing Limited, vol. 5, pp. 299-326. [CrossRef]

D'Angelo, Alfredo. 2012. Innovation and Export Performance: A Study of Italian High-Tech SMEs. Journal of Management \& Governance 16: 393-423. [CrossRef]

Dai, Meihong, Haiyang Liu, and Lingtao Lin. 2020. How Innovation Impacts Firms' Export Survival: Does Export Mode Matter? The World Economy 43: 81-113. [CrossRef]

Dai, Mi, Miaojie Yu, and Chunming Zhao. 2018. Export Tightening, Competition, and Firm Innovation: Evidence from the Renminbi Appreciation. Review of Development Economics 22: 263-86. [CrossRef]

Dalal, Dev K., and Michael J. Zickar. 2011. Some Common Myths about Centering Predictor Variables in Moderated Multiple Regression and Polynomial Regression. Organizational Research Methods 15: 339-62. [CrossRef]

Daniel, Borgia, and Newman Alexander. 2012. The Influence of Managerial Factors on the Capital Structure of Small and Medium-sized Enterprises in Emerging Economies: Evidence from China. Journal of Chinese Entrepreneurship 4: 180-205. [CrossRef]

Dehnokhalaji, Akram, Mojtaba Ghiyasi, and Pekka Korhonen. 2017. Resource Allocation Based on Cost Efficiency. Journal of the Operational Research Society 68: 1279-89. [CrossRef]

Doern, Rachel. 2009. Investigating Barriers to SME Growth and Development in Transition Environments: A Critique and Suggestions for Developing the Methodology. International Small Business Journal 27: 275-305. [CrossRef]

Ghasemaghaei, Maryam, and Goran Calic. 2020. Assessing the Impact of Big Data on Firm Innovation Performance: Big Data Is Not Always Better Data. Journal of Business Research 108: 147-62. [CrossRef]

Gonzalo, Maldonado-Guzmán, Garza-Reyes Jose Arturo, Pinzón-Castro Sandra Yesenia, and Kumar Vikas. 2019. Innovation Capabilities and Performance: Are They Truly Linked in SMEs? International Journal of Innovation Science 11: 48-62. [CrossRef] 
Gopalan, Sasidaran, and Subash Sasidharan. 2020. Financial Liberalization and Access to Credit in Emerging and Developing Economies: A Firm-Level Empirical Investigation. Journal of Economics and Business 107: 105861. [CrossRef]

Haddad, Monther I., Irene A. Williams, Mohamad Saleh Hammoud, and Rocky J. Dwyer. 2019. Strategies for Implementing Innovation in Small and Medium-Sized Enterprises. World Journal of Entrepreneurship, Management, and Sustainable Development 16: 12-29. [CrossRef]

Hayes, Andrew F. 2009. Beyond Baron and Kenny: Statistical Mediation Analysis in the New Millennium. Communication Monographs 76: 408-20. [CrossRef]

Hayes, Andrew F. 2015. An Index and Test of Linear Moderated Mediation. Multivariate Behavioral Research 50: 1-22. [CrossRef]

Hayes, Andrew F. 2018. Partial, Conditional, and Moderated Moderated Mediation: Quantification, Inference, and Interpretation Quantification, Inference, and Interpretation. Communication Monographs 85: 4-40. [CrossRef]

Heshmati, Almas. 2015. The Effect of Credit Guarantees on SMEs' R\&D Investments in Korea. Asian Journal of Technology Innovation 23: 407-21. [CrossRef]

Inui, Tomohiko, Keiko Ito, and Daisuke Miyakawa. 2017. Export Experience, Product Differentiation, and Firm Survival in Export Markets. The Japanese Economic Review 68: 217-31. [CrossRef]

Kalinga, Jagoda, Maheshwari Bharat, and Lonseth Robert. 2010. Key Issues in Managing Technology Transfer Projects: Experiences from a Canadian SME. Management Decision 48: 366-82. [CrossRef]

Kautonen, Teemu, Antti Fredriksson, Maria Minniti, and Andrea Moro. 2020. Trust-Based Banking and SMEs' Access to Credit. Journal of Business Venturing Insights 14: e00191. [CrossRef]

Lara, Agostini. 2015. Does Patenting Influence SME Sales Performance? A Quantity and Quality Analysis of Patents in Northern Italy. European Journal of Innovation Management 18: 238-57. [CrossRef]

Le, Viet, and Abbas Valadkhani. 2014. Are Exporting Manufacturing SMEs More Efficient than Non-Exporting Ones? Evidence from Australia's Business Longitudinal Database. Economic Analysis and Policy 44: 310-17. [CrossRef]

Love, James H., and Panagiotis Ganotakis. 2013. Learning by Exporting: Lessons from High-Technology SMEs. International Business Review 22: 1-17. [CrossRef]

Martuscelli, Antonio, and Gonzalo Varela. 2018. Survival Is for the Fittest: Export Survival Patterns in Georgia. Economic Systems 42: 397-413. [CrossRef]

Masood, Tariq, and Paul Sonntag. 2020. Industry 4.0: Adoption, Challenges, and Benefits for SMEs. Computers in Industry 121: 103261. [CrossRef]

Morris, Diego M. 2018. Innovation and Productivity among Heterogeneous Firms. Research Policy 47: $1918-32$. [CrossRef]

Nguyen, Khanh T. P., Thomas Yeung, and Bruno Castanier. 2017. Acquisition of New Technology Information for Maintenance and Replacement Policies. International Journal of Production Research 55: 2212-31. [CrossRef]

Ortiz-Villajos, José M., and Sonia Sotoca. 2018. Innovation and Business Survival: A Long-Term Approach. Research Policy 47: 1418-36. [CrossRef]

Oura, Mauricio Massao, Silvia Novaes Zilber, and Evandro Luiz Lopes. 2016. Innovation Capacity, International Experience, and Export Performance of SMEs in Brazil. International Business Review 25: 921-32. [CrossRef]

Park, Jong-Hyun, and Yun Bae Kim. 2019. Factors Activating Big Data Adoption by Korean Firms. Journal of Computer Information Systems, 1-9. [CrossRef]

Preacher, Kristopher J., and Andrew F. Hayes. 2008. Asymptotic and Resampling Strategies for Assessing and Comparing Indirect Effects in Multiple Mediator Models. Behavior Research Methods 40: 879-91. [CrossRef] [PubMed]

Quartey, Peter, Ebo Turkson, Joshua Y. Abor, and Abdul Malik Iddrisu. 2017. Financing the Growth of SMEs in Africa: What Are the Constraints to SME Financing within ECOWAS? Review of Development Finance 7: 18-28. [CrossRef]

Rabia, Rasheed, and Siddiqui Sulaman Hafeez. 2019. Attitude for Inclusive Finance: Influence of Owner-Managers' and Firms' Characteristics on SMEs Financial Decision Making. Journal of Economic and Administrative Sciences 35: 158-71. [CrossRef]

Robertson, Nat C. 1992. Technology Acquisition for Corporate Growth. Research-Technology Management 35: 26-30. [CrossRef] 
Rodil, Óscar, Xavier Vence, and María del Carmen Sánchez. 2016. The Relationship between Innovation and Export Behaviour: The Case of Galician Firms. Technological Forecasting and Social Change 113: 248-65. [CrossRef]

Saji, K. B., and Shashi Shekhar Mishra. 2012. Antecedents and Consequences of Technology Acquisition Intent: Empirical Evidence from Global High-Tech Industry. Journal of Strategic Marketing 20: 165-83. [CrossRef]

Saleem, Hamza, Yongjun Li, Zulqurnain Ali, Aqsa Mehreen, and Muhammad Salman Mansoor. 2020. An Empirical Investigation on How Big Data Analytics Influence China SMEs Performance: Do Product and Process Innovation Matter? Asia Pacific Business Review, 1-26. [CrossRef]

Salomon, Robert, and J. Myles Shaver. 2005. Export and Domestic Sales: Their Interrelationship and Determinants. Strategic Management Journal 26: 855-71. [CrossRef]

Salvador, Beltramino Nicolás, García-Perez-de-Lema Domingo, and Valdez-Juárez Luis Enrique. 2020. The Structural Capital, the Innovation, and the Performance of the Industrial SMES. Journal of Intellectual Capital. [CrossRef]

Schwager, Paul H., Terry Anthony Byrd, and Douglas E. Turner. 2000. Information Technology Infrastructure Capability's Impact on Firm Financial Performance: An Exploratory Study. Journal of Computer Information Systems 40: 98-105. [CrossRef]

Sen, Doruk, Melike Ozturk, and Ozalp Vayvay. 2016. An Overview of Big Data for Growth in SMEs. Procedia Social and Behavioral Sciences 235: 159-67. [CrossRef]

Song, Malin, Hongshan Ai, and Xie Li. 2015. Political Connections, Financing Constraints, and the Optimization of Innovation Efficiency among China's Private Enterprises. Technological Forecasting and Social Change 92: 290-99. [CrossRef]

Sugasawa, Yoshio, and S. Liyanage. 1999. Technology and Business Opportunities for Small and Medium Enterprises in Japan: The Role of Research Networks. International Journal of Technology Management 18: 308-25. [CrossRef]

Sun, Zhongjuan. 2014. Domestic Technological Acquisitions and the Innovation Performance of Acquiring Firms. Journal of Chinese Economic and Business Studies 12: 149-70. [CrossRef]

Tino, Woschke, Haase Heiko, and Kratzer Jan. 2017. Resource Scarcity in SMEs: Effects on Incremental and Radical Innovations. Management Research Review 40: 195-217. [CrossRef]

Tolba, Ahmed, Iman Seoudi, and Khadiga Fahmy. 2014. Factors Influencing Intentions of Egyptian MSME Owners in Taking Commercial Bank Loans. Journal of Small Business E Entrepreneurship 27: 497-518. [CrossRef]

Ullah, Barkat. 2019. Journal of Multinational Financial Firm Innovation in Transition Economies: The Role of Formal versus Informal Finance. Journal of Multinational Financial Management 50: 58-75. [CrossRef]

Wang, Dja Shin. 2019. Association between Technological Innovation and Firm Performance in Small and Medium-Sized Enterprises: The Moderating Effect of Environmental Factors. International Journal of Innovation Science 11: 227-40. [CrossRef]

Wang, Yao. 2016. What Are the Biggest Obstacles to Growth of SMEs in Developing Countries?-An Empirical Evidence from an Enterprise Survey. Borsa Istanbul Review 16: 167-76. [CrossRef]

Wellalage, Nirosha Hewa, and Viviana Fernandez. 2019. International Review of Financial Analysis Innovation and SME Finance: Evidence from Developing Countries. International Review of Financial Analysis 66: 101370. [CrossRef]

Wolff, James A., and Timothy L. Pett. 2006. Small-Firm Performance: Modeling the Role of Product and Process Improvements. Journal of Small Business Management 44: 268-84. [CrossRef]

Wu, Jie, Si Steven, and Xiaobo Wu. 2016. Entrepreneurial Finance and Innovation: Informal Debt as an Empirical Case. Strategic Entrepreneurship Journal 10: 257-73. [CrossRef]

Yacine, Haddoud Mohamed, Jones Paul, and Newbery Robert. 2018. SMEs' Export Performance in Algeria: A Configuration Approach. In Creating Entrepreneurial Space: Talking Through Multi-Voices, Reflections on Emerging Debates (Contemporary Issues in Entrepreneurship Research). Edited by David Higgins, Paul Jones and Pauric McGowan. Bingley: Emerald Publishing Limited, vol. 9A, pp. 91-111. [CrossRef]

Yatsenko, Yuri, and Natali Hritonenko. 2009. Technological Breakthroughs and Asset Replacement. The Engineering Economist 54: 81-100. [CrossRef]

Yu, Fei, and Tim Schweisfurth. 2020. International Journal of Innovation Studies Industry 4. 0 Technology Implementation in SMEs e A Survey in the Danish-German Border Region. International Journal of Innovation Studies 4: 76-84. [CrossRef] 
Zisuh, Njinyah Sam. 2018. The Effectiveness of Government Policies for Export Promotion on the Export Performance of SMEs Cocoa Exporters in Cameroon. International Marketing Review 35: 164-85. [CrossRef]

Publisher's Note: MDPI stays neutral with regard to jurisdictional claims in published maps and institutional affiliations.

(C) 2020 by the authors. Licensee MDPI, Basel, Switzerland. This article is an open access article distributed under the terms and conditions of the Creative Commons Attribution (CC BY) license (http://creativecommons.org/licenses/by/4.0/). 